International Journal of Engineering \& Technology, 7 (4.3) (2018) 456-460
International Journal of Engineering \& Technology
SPC
Website: www.sciencepubco.com/index.php/IJET
Research paper

\title{
Simulation of Taxation of Enterprises
}

\author{
Olga Ievsieieva ${ }^{1 *}$ \\ ${ }^{I}$ Ukrainian State University of Railway Transport \\ *Corresponding author E-mail: polkya@meta.ua
}

\begin{abstract}
In the article, a taxation methodology is proposed for enterprises of the agricultural sector of the economy which allows forecasting tax revenues. The model is based on the correlation and regression analysis. The author suggests using the paired comparison and prioritization methods for the scientific rationale of the choice of the model. The effectiveness of the company's fiscal policy is determined based on the value of the coefficient, which is calculated as the ratio of the actual amount of collected taxes to their amount obtained by calculation using the regression equation. The methodology can be used by the managers of the agricultural sector of the economy to compare the performance of the enterprises and the rationale for incentives. The utilization of the results of the analysis is reasonable for justification of investment projects with the objective of developing the agricultural sector of the regional economy.
\end{abstract}

Keywords: Correlation and regression analysis; Effectiveness; enterprise; Fiscal policy; Forecasting; Simulation; Taxation.

\section{Introduction}

In the context of the specificity of the current social and economic development of Ukraine, the necessity of the study of the problems of economic evaluation of the performance of agricultural enterprises is becoming more urgent, since the scope of application of the results of such an assessment expands significantly [6]. The study of the issues of stimulation and assessment of taxation of agricultural enterprises is getting more relevant since their results can be used to solve the practical problems, such as fiscal analysis, analysis and planning of the business operations of the enterprise, justification of tasks for individual units manufacturing arable farming products; the organization of efficient use of lands (determining the optimal area, labor and material resources of production units, overall production and sales volumes of products); development of measures to improve the productive and technological properties of lands in order to increase soil fertility and reduce costs in arable farming; regulation of land-relate matters (provision of rationale of labor remuneration in contracting and land rent in land leasing cases); control over land utilization and protection of land; resolving disputes between renters and landlords, owners and land users; establishment of a compensation amount for losses (damages) in connection with the seizure and redistribution of land, due to natural disasters.

The relevance and choice of the topic of the study are determined by the importance of a proper economic assessment of taxation of agricultural enterprises in the context of the specificity of the present-day social and economic development of Ukraine.

The purpose of our study is to justify the expediency of the practical utilization of the developed methodology for stimulation of taxation of enterprises and the forecast of tax revenues in the work of economic departments of the management of the agricultural sector of the territories [5].

\section{Existing Work}

Today, critical social and economic transformations are taking place in the agricultural sector of the Ukrainian economy, however, their effectiveness leaves much to be desired, mostly due to the imperfection of the tax relation system, which predetermines in many ways both the disparity of prices and the limited potential of effective demand both for agricultural products, and the capital items necessary in the country.

Disadvantages of the current taxation system are related to the fact that up to the present time it has failed to become a result of the systemic economic analysis, is formed as a compromise between different, including completely opposite opinions and interests.

It should be noted that the Ukrainian taxation legislation focuses mainly on the fiscal function of taxes, while the regulation of the economy should also perform the function of stimulating the growth of productive forces and the localization of economic pathologies. Therefore, the deficiencies of the existing tax system are one of the destabilizing factors in the development of the economy, and its improvement becomes an urgent national need, which cannot be ignored either in theory or in practice. The problems of optimizing the size of the tax potential and the tax burden, the relationship between them both at the macro and micro levels of the national economy should be thoroughly studied. In the publications of the last decade, insufficient attention seems to be paid to the systematic investigation of the problems of the development of tax relations in association with the problem of optimizing the functioning of the national economy [3]. In particular, the issues of assessment of effectiveness of the tax system stimulating the agricultural production have not been properly represented in the scientific literature, little attention has been paid to stimulation of tax relations, and the problem of measuring the multiplicative effect of the improvement of tax relations has not been considered at all. 
The main feature that has to be faced in the development of tax relations in the agricultural sector of the Ukrainian economy is the uniqueness of the land, which is both an object, means and a spatial basis for labor, and therefore the basis for calculation of taxes. At the same time, it is essential to take into account the fact that such economic pathology as rental relations that are formed due to the existence of sustainably unequal relations in the use of lots of different quality plays a special role in tax relations.

If the taxation is based on proportion to the amount of land, this results in the increased cost of production on the worse lands, and, consequently, the higher price of agricultural products being sold This restricts customer demand and reduces the competitiveness of the agricultural production. Beneficiaries from this type of taxation of land are the owners of the better land plots, since in these plots the profit increases (due to the increased prices of agricultural products), which upon the renewal of lease contracts, as a result of competition between tenants, is taken by land owners. If the land tax depends not on the quantity but on the quality of the land, the tax becomes actually a rent tax, and then it does not inflate the price of the manufactured agricultural products. Therefore, if the tax policy does not follow the principle of protection of the interests of private landowners, whose number is likely to increase in the near future, it should facilitate the repayment of land rent.

The tax system in the agricultural sector of the Ukrainian economy should not only take into account the variety of forms of rental relations, but also regulate them, which requires specific quantitatively knowledge, in what enterprises and to what extent the land rent is formed. The most appropriate way of the rent extraction seems to be the rental payment system, calculated on the basis of a flexible assessment of the land, which allows summarizing the economic characteristics of its productivity, location, and the effectiveness of successive costs

Tax relations can be either the form of normal relations (when the tax system is stable, stimulates the development of productive forces) and in the form of economic pathologies, if taxes are structures in such a way that they exercise primarily fiscal functions.

A stable tax system optimizes the conditions for effective development of the agricultural sector of the Ukrainian economy, and the difference between the tax potential and the tax burden tends to zero in the long run.

Promising areas of further scientific developments aimed at improving the tax relations in the agricultural sector of the economy include the development of a structure of an economicmathematical model optimizing the tax relations; identification of the trends of transformation of the tax structure aimed at increasing the economic efficiency of agricultural production; further more specific theoretical research on this issue, solving specific practical problems of increasing the efficiency of agricultural production.

Taxation may and should be considered not only as the dominant source of the formation of centralized national financial resources, but also as a tool of the governmental regulation of the economy to stimulate and support the activities of individual industries.

The specific features of taxation in the agricultural sector of the economy include tax incentives for attracting investments; the need for environmental taxation; preferential order of collection of taxes and levies; a special scheme of land taxation; the use of a flat agricultural tax.

The Ukrainian system of agricultural taxation is characterized by frequent changes. Over the past two decades, it has undergone transformations from a unified approach for all industries to the creation of special conditions for the agriculture and, ultimately, the introduction of a special taxation scheme (a flat agricultural $\operatorname{tax})$.

The structure of taxes and levies in the agricultural sector of the economy does not promote the effective implementation of the stimulating function of taxation. This system must be restructured with focus on direct taxes and taxation of the productive and resource potentials, and income; its structure should be harmonized.

Our analysis has revealed that the application of a flat agricultural tax is economically feasible for small agricultural enterprises and farmers with a medium level of profitability.

In order to strengthen the environmental component of agricultural taxation, it is proposed to focus on measures that stimulate investment in environmental and energy-saving measures. Such tools may include additional accelerated depreciation, tax deduction, and reduction of the tax base for the amount of funds invested in such measures.

To improve the effectiveness of performance of the tax system, any information on the amount of administrative costs for the introduction of new and exercising the existing taxation mechanisms should also be open. Not only the administrative costs of fiscal authorities, but also the economic costs of taxpayers should be evaluated.

Today, the same indicators are used as effectiveness criteria for the fiscal policy of enterprises as for the effectiveness of the functioning of enterprises, such as different indicators of profitability, depending on their industry. The problem of developing a unified approach to assessing the effectiveness of their fiscal policy becomes ever more relevant. For example, the profit-to-cost ratio of production is used as an indicator of profitability in assessing the performance of industrial and agricultural enterprises, but it is not applicable to trading enterprises. At present, there are only few scientific approaches that take into account multiple factors affecting the formation of profits and the amount of taxes. Today, computer equipment of enterprises and companies enables using such methods of assessment [2, 4] of the effectiveness of fiscal policy of enterprises based on the use of economic and statistical methods which have been previously unavailable due to of the extensive calculations.

\section{Results and Discussion}

Analysis of the effectiveness of fiscal policy of enterprises was carried out on the basis of data on the performance of the most typical profitable agricultural enterprises in 25 districts of Kharkov region in 2017 (Table 1).

Table 1: Correlation matrix of the factors that have a material effect on the amount of the paid taxes

\begin{tabular}{|c|c|c|c|c|c|c|}
\hline Factors & $\mathrm{Y}$ & $\mathrm{X}_{1}$ & $\mathrm{X}_{2}$ & $\mathrm{X}_{3}$ & $\mathrm{X}_{4}$ & $\mathrm{X}_{5}$ \\
\hline $\mathrm{Y}$ & 1.000 & 0.770 & 0.335 & 0.179 & 0.670 & 0.671 \\
\hline $\mathrm{X}_{1}$ & & 1.000 & 0.342 & 0.349 & 0.593 & 0.639 \\
\hline $\mathrm{X}_{2}$ & & & 1.000 & 0.161 & 0.290 & 0.563 \\
\hline $\mathrm{X}_{3}$ & & & & 1.000 & 0.578 & 0.199 \\
\hline $\mathrm{X}_{4}$ & & & & & 1.000 & 0.578 \\
\hline $\mathrm{X}_{5}$ & & & & & & 1.000 \\
\hline
\end{tabular}

The data were processed on the persona computer using the specially developed applied software package. On the basis of the factors with the most significant correlation coefficient values, the following regression functions were plotted:

$\mathrm{T}_{\text {calculated paid }}=\mathrm{f}\left(\mathrm{X}_{1}, \mathrm{X}_{2}, \ldots, \mathrm{X}_{\mathrm{n}}\right)$,

where $\mathrm{H}_{\text {calculated paid }}$ - amount of paid taxes calculated using the regression equations.

Parameters of the obtained regression equations are given in Table 2.

Table 2: Parameters of the regression equations

\begin{tabular}{|c|c|c|c|c|}
\hline \multirow[b]{2}{*}{ Parameters } & \multicolumn{4}{|c|}{ Factors used for the analysis } \\
\hline & $\begin{array}{c}\mathrm{X}_{1}, \mathrm{X}_{2}, \\
\mathrm{X}_{4}, \mathrm{X}_{3}, \mathrm{X}_{5} \\
\end{array}$ & $\begin{array}{l}\mathrm{X}_{1}, \mathrm{X}_{3}, \\
\mathrm{X}_{4}, \mathrm{X}_{5}\end{array}$ & $\mathrm{X}_{1}, \mathrm{X}_{4}, \mathrm{X}_{5}$ & $\mathrm{X}_{5}, \mathrm{X}_{6}$ \\
\hline Free term $\mathrm{A}_{0}$ & $-1,224$ & $-1,248$ & -874 & $-1,263$ \\
\hline $\begin{array}{r}\text { Coefficients: } \\
\mathrm{A}_{1}\end{array}$ & 0.013 & 0.013 & 0.012 & - \\
\hline
\end{tabular}




\begin{tabular}{|lc|c|c|c|c|}
\hline & $\mathrm{A}_{2}$ & -0.578 & - & - & - \\
\hline & $\mathrm{A}_{3}$ & -0.043 & -0.043 & - & - \\
\hline & $\mathrm{A}_{4}$ & 100.87 & 101.02 & 58.82 & 94.81 \\
\hline $\mathrm{A}_{5}$ & 2.31 & 2.252 & 3.460 & 6.88 \\
\hline $\begin{array}{l}\text { Correlation } \\
\text { coefficient (R) }\end{array}$ & 0.860 & 0.860 & 0.829 & 0.755 \\
\hline $\begin{array}{l}\text { Determination } \\
\text { coefficient (R }\end{array}$ & 0.740 & 0.740 & 0.688 & 0.570 \\
\hline $\begin{array}{l}\text { Durbin-Watson } \\
\text { coefficient (K }\end{array}$ & 2.370 & 2.361 & 1.998 & 1.958 \\
\hline
\end{tabular}

The Durbin-Watson criterion was used to verify the autocorrelation [3]. If there is no autocorrelation, then its value will be 2 , and in case of full autocorrelation, it will be equal to either 0 or 4 . Its value determines the correctness of the obtained regression equation.

The results of the calculations summarized in Table 2 showed that the optimal value of the Durbin-Watson coefficient was 1.997726 in the case when the three-factor model $\mathrm{T}_{\text {calculated paid }}$ $=\mathrm{f}\left(\mathrm{X}_{1}, \mathrm{X}_{4}, \mathrm{X}_{5}\right)$ is used, which indicates almost complete absence of autocorrelation, and, consequently, the correctness of the regression equation found.

In our case, the equation of regression has the form:

$\mathrm{T}_{\text {calculated paid }}=-874+0.012 \mathrm{X}_{1}+58.82 \mathrm{X}_{4}+3.460 \mathrm{X}_{5}$.

The determination coefficient, which is the square of the correlation coefficient showing the share of the explained variation in the entire range of changes, was 0.688 . Its value suggests that in the above regression equation, $68.8 \%$ of the factors affecting the amount of taxes paid by the agricultural enterprises have been taken into account.

The coefficients of the regression equation characterize the quantitative effect of the considered factors on the amount of taxes paid by agricultural enterprises. They show by how many thousands UAH their value changes when a factor sign changes by one unit. As we can see, if the total volume of agricultural production increases by 1,000 UAH, the amount of paid taxes increases by UAH 120, and with each extra vehicle a tax increases by UAH 3.46 thousand.

Further, we determined the calculated values of the amount of taxes of agricultural enterprises for each district of Kharkov Region using the found regression equation (Table 3 ).

The effectiveness of fiscal policy of an agricultural enterprise was determined by solving the expression below for each enterprise:

$\mathrm{C}_{\mathrm{iEFP}}=\mathrm{T}_{\text {actual i }} / \mathrm{T}_{\text {calculated } \mathrm{i}}$

where $\mathrm{C}_{\text {iEFP }}$ - effectiveness coefficient of fiscal policy of the i-th enterprise, units;

$\mathrm{T}_{\text {actual } \mathrm{i}}$ - actual amount of paid taxes of the i-th enterprise, thousand UAH;

$\mathrm{T}_{\text {calculated } \mathrm{i}}$ - amount of paid taxes of the i-th enterprise, calculated using the regression equation.

Table 3: Analysis of effectiveness of fiscal policy of agricultural enterprises

\begin{tabular}{|c|c|c|c|}
\hline \multirow{2}{*}{$\begin{array}{c}\text { District of } \\
\text { Kharkov } \\
\text { Region, No. } \\
\text { (conditional) }\end{array}$} & \multicolumn{2}{|c|}{$\begin{array}{c}\text { Amount of paid taxes, } \\
\text { thousand UAH }\end{array}$} & \multirow{2}{*}{$\begin{array}{c}\text { Effectiveness } \\
\text { coefficient of fiscal } \\
\text { policy, units } \\
\mathrm{K}_{\text {i EFP }}\end{array}$} \\
\hline & $\begin{array}{l}\text { Actual } \\
\mathrm{T}_{\text {actual }}\end{array}$ & $\begin{array}{c}\text { Calculated } \\
\mathrm{T}_{\text {calculated }}\end{array}$ & \\
\hline 1 & 4891.9 & $8,611.091$ & 0.568093 \\
\hline 2 & 8186.6 & $10,735.12$ & 0.7626 \\
\hline 3 & 19656.6 & $20,075.05$ & 0.979156 \\
\hline 4 & 3003.3 & $3,381.81$ & 0.888075 \\
\hline 5 & 4960.7 & $6,098.695$ & 0.813404 \\
\hline 6 & 5472.6 & $5,537.886$ & 0.988211 \\
\hline 7 & 9027.8 & $7,705.16$ & 1.171656 \\
\hline 8 & 8148.6 & $7,927.225$ & 1.027926 \\
\hline 9 & 9211.5 & $8,147.338$ & 1.130615 \\
\hline 10 & 5387.8 & $5,759.485$ & 0.935466 \\
\hline 11 & 4114.4 & $4,984.784$ & 0.825392 \\
\hline
\end{tabular}

\begin{tabular}{|c|c|c|c|}
\hline 12 & 5,087 & $9,093.101$ & 0.559435 \\
\hline 13 & 3503.5 & $4,075.968$ & 0.85955 \\
\hline 14 & 7851.3 & $4,164.043$ & 1.885499 \\
\hline 15 & 9481.4 & $11,867.88$ & 0.798913 \\
\hline 16 & 17,658 & $7,412.771$ & 2.382105 \\
\hline 17 & $10,010.4$ & $9,554.097$ & 1.04776 \\
\hline 18 & $4,343.3$ & $6,102.878$ & 0.711681 \\
\hline 19 & $7,801.1$ & $7,793.43$ & 1.000984 \\
\hline 20 & $7,197.3$ & $8,440.768$ & 0.852683 \\
\hline 21 & $4,606.5$ & $5,812.57$ & 0.792507 \\
\hline 22 & $8,851.2$ & $8,620.629$ & 1.026747 \\
\hline 23 & 804.1 & 889.0814 & 0.904417 \\
\hline 24 & $3,186.8$ & $3,199.798$ & 0.995938 \\
\hline 25 & $20,454.2$ & $16,907.23$ & 1.20979 \\
\hline
\end{tabular}

Absolute and relative deviations of the amount of paid taxes are summarized in Table 4.

Table 4: Absolute and relative deviations of the amount of paid taxes

\begin{tabular}{|c|c|c|}
\hline \multirow{2}{*}{$\begin{array}{l}\text { District of Kharkov } \\
\text { Region, No. } \\
\text { (conditional) }\end{array}$} & \multicolumn{2}{|c|}{$\begin{array}{c}\text { Deviations }\left(\mathrm{H}_{\text {actual }}-\mathrm{H}_{\text {calculated }}\right) \\
\text { thousand UAH }\end{array}$} \\
\hline & $\begin{array}{c}\text { Absolute, } \\
\text { thousand UAH }\end{array}$ & Relative, $\%$ \\
\hline 1 & -3719.19 & -43.1907 \\
\hline 2 & -2548.52 & -23.74 \\
\hline 3 & -418.447 & -2.08441 \\
\hline 4 & -378.51 & -11.1925 \\
\hline 5 & -1137.99 & -18.6596 \\
\hline 6 & -65.2861 & -1.1789 \\
\hline 7 & 1322.64 & 17.16563 \\
\hline 8 & 221.3755 & 2.792598 \\
\hline 9 & 1064.162 & 13.06146 \\
\hline 10 & -371.685 & -6.45344 \\
\hline 11 & -870.384 & -17.4608 \\
\hline 12 & -4006.1 & -44.0565 \\
\hline 13 & -572.468 & -14.045 \\
\hline 14 & 3687.257 & 88.54992 \\
\hline 15 & -2386.48 & -20.1087 \\
\hline 16 & 10245.23 & 138.2105 \\
\hline 17 & 456.3037 & 4.776 \\
\hline 18 & -1759.58 & -28.8319 \\
\hline 19 & 7.669922 & 0.098415 \\
\hline 20 & -1243.47 & -14.7317 \\
\hline 21 & -1206.07 & -20.7493 \\
\hline 22 & 230.5713 & 2.674646 \\
\hline 23 & -84.9814 & -9.55834 \\
\hline 24 & -12.9978 & -0.40621 \\
\hline 25 & 3546.971 & 20.97902 \\
\hline
\end{tabular}

Based on the data summarized in Table 3, a diagram of values of the effectiveness coefficient of fiscal policy of the studied agricultural enterprises was plotted (Figure 1).

$\mathrm{C}_{\text {i EFP }}$ 


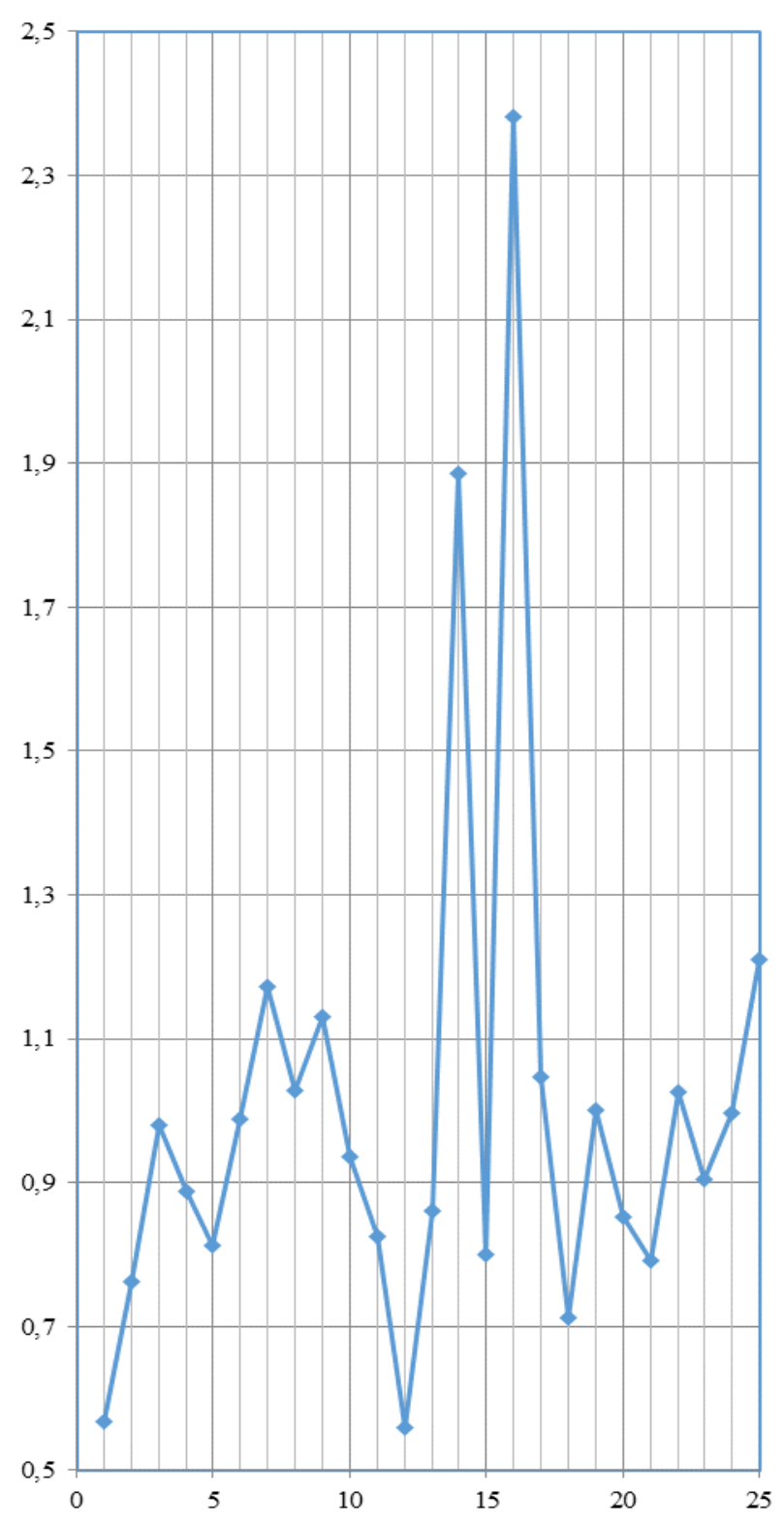

Fig. 1: Values of the effectiveness coefficient of fiscal policy of Enterprises agricultural enterprises.

The fiscal policy of agricultural enterprises in a certain district of Kharkov Region can be recognized as effective in cases where the value of the coefficient is greater than one. The value of the coefficient greater than one means that the actual amount of taxes paid by enterprises in Kharkov region is more than the average for the selected sample. In our case, the fiscal policy of the enterprises in districts $7,8,9,14,16,17,19,22,25$ for the considered period can be regarded satisfactory.

Also a diagram of actual and calculated tax amounts of the enterprises in the investigated districts was plotted (Figure 2).

Subsequent questionnaire survey of the officials of fiscal departments of the Kharkov Region and employees of agricultural enterprises showed that the developed methodology for determining the effectiveness of fiscal policy is simple in terms of calculation and is easy to understand by every economic analyst. Utilization of the methodology in the analytical practice of the officials of the fiscal departments and the managers of agricultural enterprises will improve the quality of the comparative analysis in this sphere and the accuracy of assessment when used together with the conventional performance indicators.

$\mathrm{UAH}$

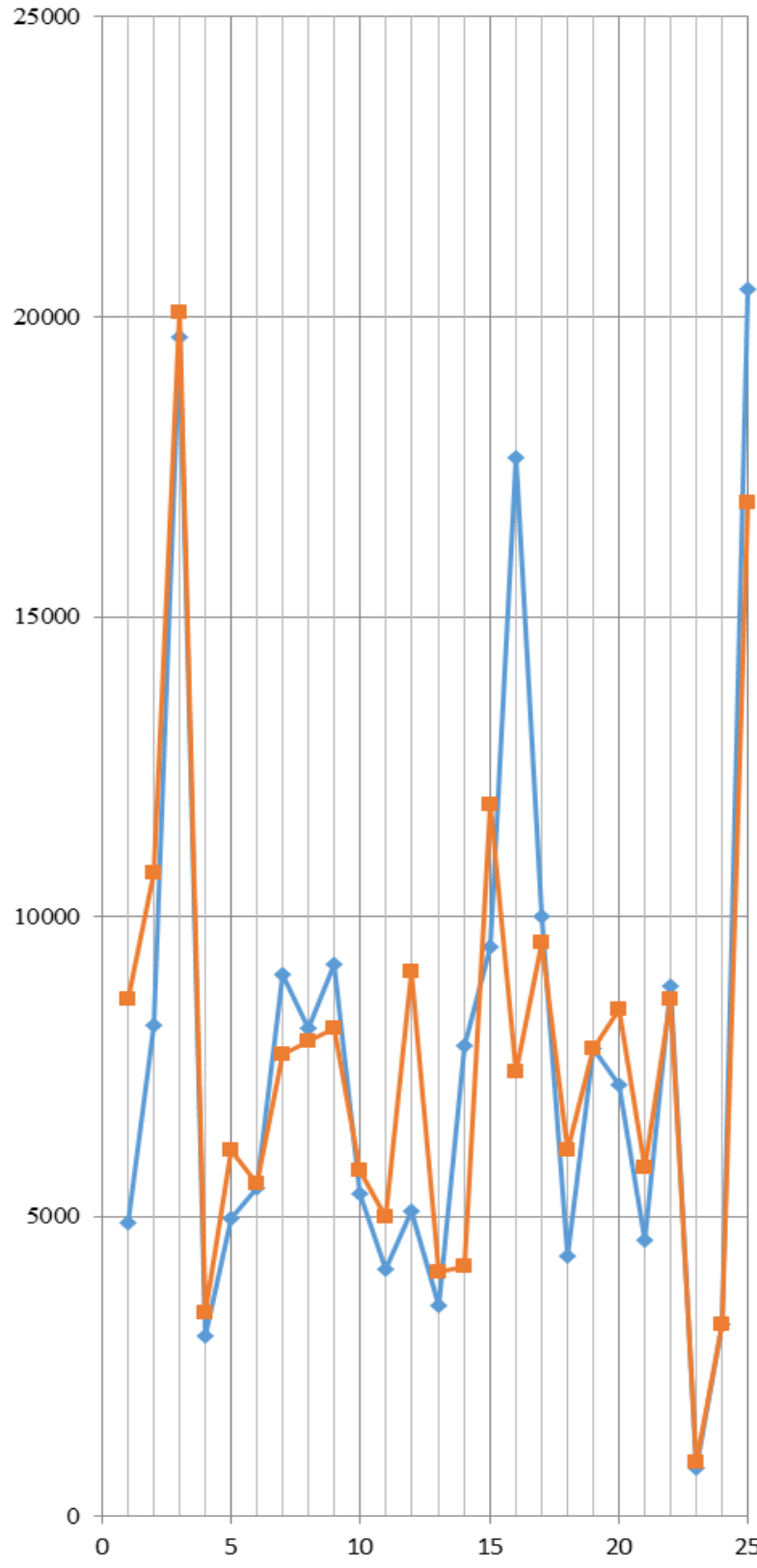

Enterprises

Fig. 2: Actual and calculated amounts of paid taxes in the investigated districts of Kharkov Region.

The flexibility of the methodology is worth mentioning, since it allows taking into account multiple factors effecting the amount of taxes paid by the enterprise and the reasonability of its application for assessment of the effectiveness of the fiscal policy of not only agricultural enterprises, but also enterprises of other business types in the region provided the factor characteristics were properly selected.

\section{Conclusion}

The following conclusions have been made on the basis of the conducted study.

1. Tax regulation of the business operations of enterprises can be considered effective if it provides for prompt responding to changing business conditions, preventing the negative impact of environmental factors, improving the mechanism for implementing fiscal policy.

2. The mechanism of taxation management of agricultural producers is a set of managerial actions of governmental authorities, economic management and audit authorities, public 
supervision bodies and professional organizations which are executed by them together with agricultural producers during collection of tax payments and have the purpose of providing a stimulating effect of the tax system on the development of the agricultural sector, the implementation of both regulatory and fiscal functions of taxes, the elimination of deficiencies of the existing tax collection methods, the formation of an optimal taxation system.

3. The mechanism of taxation management of agricultural producers should provide for effective functioning of all its elements through: identifying issues of the development of the agricultural sector; determining strategic and tactical objectives of its development, the hierarchy of the set objectives according to their priority and concentration of efforts to achieve the most important of them; analyzing positive foreign experience and opportunities to adjust it for the domestic conditions; analyzing alternative ways to achieve objectives; evaluating economic results, benefits, losses, risks; efficiency evaluation; adjustment of the mechanism depending on such factors, as time/economic situation or regional specificities.

4. On the basis of generalization of the taxation practice of agricultural producers in Ukraine and abroad, the following areas for its development could be determined: simplification of the tax system, reducing the tax burden; tax incentives for renewal and technical renovation of fixed assets, resource saving, rational use of agricultural land; as well as investment and innovation. In Ukraine, the above areas are not currently being implemented in practice, but are just formal and declarative; therefore they should be considered while developing ways to improve the organizational and economic taxation mechanism of agricultural producers.

5. Integration processes which have been naturally strengthened in the field of agricultural production in the recent years caused stipulated the formation of vertical and horizontal integrated structures of various organizational forms, various forms of international economic cooperation which resulted in the increased volume and intensity of the relationships and interaction within the existing mechanism and occurrence of new management levels. Recognizing the harmonization as the main principle of steadiness and stability of the complex and large systems, which are formed during integration or in which such processes occur, the rationale has been provided for the necessity of dual representation and using the term "harmonization" as a process of reaching mutual accord and as an relevant state (result) of this process; adjustment of the content of legislative and regulatory documents with the purpose of the corresponding replacement of the term "adaptation" with the term "harmonization"; the necessity to consider harmonization not as a goal in itself, but as a means or a tool of creating an efficient mechanism for taxation management; the importance of taking into account its different types which allow integrated presentation of its manifestation.

6. In the course of the study, a methodology for forecasting of tax revenues were developed and tested. The relevance of the scientific development of this problem is increasing since such forecasts are necessary to compile medium- and long-term plans, and to develop the general strategy of the enterprise.

Special "Trend" software was developed to forecast the amount of tax revenues, which was used for forecasting based on 5 mathematical models, such as linear, logarithmic, polynomial, power, and exponential ones.

In addition to the above 5 models, it is reasonable to use multifactor correlation and regression analysis to determine the forecasted value of tax revenues.

In the course of the study, we selected factors that have material effect on the amount of tax revenue based on the calculation of correlation coefficients.

Data were processed on a personal computer using a specially developed add-on to MS Excel.
7. Practical officials of fiscal departments currently substantiate the forecasted values mainly intuitively, relying on their professional experience, emerging trends in the taxation of profits of enterprises. We propose to use the paired comparison and prioritization methods as a unique mathematical apparatus for the scientific rationale of the choice of the forecasting model.

8. The tax forecasting model based on the multifactor correlationregression analysis was received the highest estimation when the paired comparison and prioritization methods and specially developed software were used.

9. The conducted questionnaire survey of the officials of fiscal departments of Kharkov region showed that the proposed methodological approach to assessment of models of tax forecasting using the paired comparison and prioritization methods and a specially developed software application is simple in terms of calculation and is easy to understand by every employee. Utilization of the methodology in the analytical practice of tax department officials will improve the quality of analytical economic work.

10. Today, the same indicators are used as criteria for the effectiveness of the tax policy of agricultural enterprises as for the effectiveness of the performance of enterprises of other types of business activity: different profitability indicators, depending on the sector of economy where they are used. The problem of developing a unified approach to the assessment is getting more relevant. Using the effectiveness coefficient of fiscal policy is proposed to determine the effectiveness of the fiscal policy of the enterprise, this coefficient being defined as the ratio of actual taxes to their estimated value, using the specially developed addon to the MS Excel "Multifactor correlation and regression analysis".

11. The conducted questionnaire survey of the officials of fiscal departments of Kharkov Region and employees of agricultural enterprises showed that the developed methodology for determining the effectiveness of fiscal policy is simple in terms of calculation and is easy to understand by every employee of the economic departments. Utilization of the methodology in the analytical practice of the officials of the fiscal departments and the managers of agricultural enterprises will improve the quality of the comparative analysis and the accuracy of assessment when used together with the conventional performance indicators.

\section{References}

[1] Anatolyev S. Durbin-Watson statistic and random individual effects // Econometric Theory (Problems and Solutions). - 20022003.

[2] Hamilton J.D. (2004).Time Series Analysis. Princeton University Press, Princeton, New Jersey. -114 p.

[3] Ievsieieva O.O. (2013) Innovatsiinyi rozvytok ahrarnoho sektora Ukrainy $v$ umovakh hlobalizatsii [Innovative development of the agricultural sector of Ukraine in the context of globalization]. Business inform, No. 3 (422), pp. 151-157.

[4] Judge, G.G., Hill, R.C. \& Griffiths W.E. (2014).The Theory and Practice of Econometrics. N. Y, John Wiley and Sons. -356 p.

[5] Pakulin S.L., Feklistova IS \& Feklistov MV (2017), "Selection and evaluation of the effectiveness of land use policies and resource consumption for agricultural enterprises", Proceedings of VII International scientific conference "New achievements of world science”, Morrisville, Jun 22, 2017. Morrisville, Lulu Press, 2017, pp. 33-37. (in Rus.).

[6] Pakulin S.L., Feklistova I.S., Tsypkin Y.A. \& Pakulina A.A. (2017) "Sustainable development of the agricultural sector of the regional economy", Proceedings of II International scientific conference "Innovations in science and technology", Oct 31, 2017. London, SI Universum, 2017. pp. 25-34. (in Rus.). 